CZASOPISMO INŻYNIERII LA¿DOWEJ, ŚRODOWISKA I ARCHITEKTURY JOURNAL OF CIVIL ENGINEERING, ENVIRONMENT AND ARCHITECTURE

JCEEA, t. XXXIII, z. 63 (3/16), lipiec-wrzesień 2016, s. 421-430

\author{
Izabela SKRZYPCZAK ${ }^{1}$ \\ Janusz KOGUT ${ }^{2}$ \\ Lidia BUDA- OŻóG ${ }^{3}$ \\ Joanna KUJDA ${ }^{4}$
}

\title{
ZALECENIA NORMOWE W OCENIE STANU TECHNICZNEGO DROGOWEJ KONSTRUKCJI INŻYNIERSKIEJ NA PRZYKŁADZIE BADAŃ WYBRANYCH CECH FIZYKO-CHEMICZNYCH
}

\begin{abstract}
Ważnym zagadnieniem mającym decydujący wpływ w ocenie stanu technicznego całej konstrukcji ma jakość materiału konstrukcyjnego, z którego jest on wykonany. Dla żelbetowych wiaduktów drogowych zagrożeniem dla betonu są: dwutlenek węgla, zawarty w atmosferze, chlorki, pochodzące z soli powszechnie stosowanych do odladzania oraz związki siarki pochodzące ze spalin. W wyniku kombinacji tych agresywnych czynników następuje albo zobojętnianie betonu albo skażenie go. Głównym aspektem poruszanym w pracy są różne zalecenia normowe dotyczące zawartości chlorków w betonie konstrukcyjnym oraz próba ich weryfikacji według podejścia probabilistycznego. Celem artykułu jest ocena stanu betonu w elementach wiaduktu w oparciu o wyniki badań laboratoryjnych. Badaniami objęto rdzenie betonowe pobrane $\mathrm{z}$ różnych elementów badanego obiektu, które w obserwacjach makroskopowych nie wykazywały uszkodzeń korozyjnych. Wykonano badania fizyko-mechaniczne betonu, określono jego skład oraz zawartości chlorków, siarczanów i zasięg karbonatyzacji. Korzystając ze standardowej procedury stwierdzono przekroczenie wartości progowej chlorków dla spodu konstrukcji. Ryzyko inwestora dla przekroczenia wartości progowej oszacowano na podstawie przyjętych funkcji gęstości na ok. $1 \%$.
\end{abstract}

Słowa kluczowe: mosty drogowe, beton, chlorki

\footnotetext{
${ }^{1}$ Autor do korespondencji / corresponding author: Izabela Skrzypczak, Politechnika Rzeszowska, Zakład Geodezji i Geotechniki, ul. Poznańska 2, 35-959 Rzeszów; tel. 178651010; izas@prz.edu.pl

2 Janusz Kogut, Politechnika Krakowska, ul. Warszawska 24, 31-155 Kraków; jkogut@pk.edu.pl

${ }^{3}$ Lidia Buda-Ożóg, Politechnika Rzeszowska, Katedra Konstrukcji Budowlanych, ul. Poznańska 2, 35-959 Rzeszów; lida@prz.edu.pl

${ }^{4}$ Joanna Kujda, Politechnika Rzeszowska, joannakujda@wp.pl
} 


\section{Wprowadzenie}

Od konstrukcji budowlanych wymaga się, aby w przyjętym okresie eksploatacji zapewniona była ich zdolność do użytkowania przy zachowaniu określonych minimalnych cech wytrzymałościowych. Konieczność przedłużenia czasu eksploatacji obiektu wiąże się z potrzebą remontowania lub wzmacniania poszczególnych elementów konstrukcji mostowej. Jest to zadanie trudne i złożone, a przy tym gospodarczo ważne.

W konstrukcjach mostowych zarówno żelbetowych, jak i sprężonych podstawową ochronę strukturalną zbrojenia spełnia beton i razem ze stalą jest głównym materiałem konstrukcyjnym. Beton (także wykonane z niego elementy konstrukcji) uważano przez wiele lat za materiał odporny na korozję. Wzrost agresywności środowiska, praca elementów mostowych w warunkach cyklicznego zamrażania i odmrażania oraz stosowanie odladzających związków soli, a także wiele błędów projektowych i wykonawczych sprawiły, że w ostatnich latach obserwuje się wyraźne zwiększenie korozji betonu w konstrukcjach mostowych. Destrukcyjne oddziaływanie środowiska na beton prowadzi do obniżenia jego właściwości użytkowych i rozpoczyna się zwykle zmianami zaatakowanej powierzchni, a następnie postępuje w głąb danego materiału wybiórczo, drogą najefektywniejszego działania, niszcząc substancje najbardziej na nią podatne.

\section{Przyczyny korozji betonowych elementów konstrukcyjnych}

Do podstawowych przyczyn powodujących stosunkowo szybkie tempo korozji mostów betonowych można zaliczyć narażenie konstrukcji mostowej na bezpośrednie oddziaływanie środowiska podczas eksploatacji, to jest oddziaływanie zmiennych warunków temperaturowych i wilgotnościowych, duże gradienty cyklicznie zmiennych obciążeń, oddziaływanie toksycznych spalin, działanie soli odladzających itp. Destrukcyjne oddziaływanie na mosty może dotyczyć zarówno betonu, jak i stali zbrojeniowej.

Do zewnętrznych czynników wywołujących korozję betonu można zaliczyć fizyczne oddziaływanie środowiska, które powoduje łuszczenie i pękanie, a także reagujące $\mathrm{z}$ betonem substancje chemiczne (miękkie wody, kwasy, sole odladzające czy siarczany) wywołujące korozję ługującą lub pęczniejącą. Do wpływów wewnętrznych można zaliczyć działanie mechaniczne spowodowane zmęczeniem, naprężeniami, dochodzi wówczas do pęknięć i zarysowań konstrukcji, a także niewłaściwą jakość składników betonu (cement o nadmiernej zawartości siarczanów, alkaliów, glinianów oraz reaktywne kruszywo) powodującą także pęcznienie, rozsadzanie i łuszczenie betonu. Uszkodzenie mikrostruktury sprzyja wnikaniu czynników agresywnych w głąb elementu konstrukcji, prowadząc do strefowych zmian w składzie chemicznym betonu. Korozja wewnętrzna prowadzi do zmian zachodzących w całym przekroju elementu betonowego - w stwardniałym zaczynie cementowym lub w strefie kontaktowej kruszywo-zaczyn, a powstające pęczniejące produkty reakcji niszczą wewnętrzną mikrostrukturę. 
Obserwowane zniszczenie betonu może być w każdym przypadku różne w zależności od jakości betonu, stopnia agresywności środowiska, ukształtowania konstrukcji. Mechanizm działania korozji ługującej związany jest z rozpuszczaniem i wymywaniem wodorotlenku wapniowego, a także innych składników stwardniałego zaczynu cementowego. Prowadzi to do zniszczenia mikrostruktury betonu i wzrostu jego porowatości. Szczelność betonu jest istotnym parametrem zmniejszającym podatność konstrukcji na tę korozję. Objawem tej korozji obserwowanym na powierzchni jest łuszczenie betonu oraz powstawanie wykwitów, tworzących się na powierzchni betonu w wyniku odparowania wody przesiąkającej przez niego i pozostawiającej naloty z wypłukanych soli.

Działanie korozji chlorkowej na elementy betonowe jest wywołane użyciem soli odladzających w okresie zimowym do utrzymania przejezdności mostu. Jeśli beton jest całkowicie nasycony wodą, chlorki przenikają przez otulinę zbrojenia w wyniku dyfuzji. W częściowo zawilgoconym betonie, migracja chlorków może być także wywołana w wyniku absorpcji i podciągania kapilarnego. $\mathrm{Z}$ chwilą, kiedy stężenie chlorków rozpuszczonych w cieczy porowej osiągnie wartość krytyczną, następuje uszkodzenie warstewek pasywnych na powierzchni stali i rozpoczyna się korozja, a postęp niszczenia zbrojenia jest w środowiskach chlorkowych bardzo szybki, zaś czas po którym chlorki osiągną powierzchnię zbrojenia jest równoznaczny z okresem użytkowania konstrukcji. Główne mechanizmy niszczenia betonu przez roztwory chlorkowe to reakcja chlorków z wodorotlenkiem wapnia lub fazą C-S-H, w wyniku której tworzą się pęczniejące zasadowe chlorki wapniowe lub magnezowe. Powstawanie soli Friedla ostatnio uznaje się za czynnik korzystny, ze względu na wiązanie jonów chlorkowych i zmniejszanie ich zawartości w fazie ciekłej betonu.

$\mathrm{W}$ wyniku oddziaływania dwutlenku węgla $\mathrm{z}$ powietrza beton $\mathrm{z}$ upływem czasu ulega karbonatyzacji. Dwutlenek węgla wnikając w głąb betonu reaguje przede wszystkim z wodorotlenkiem wapnia, a także z innymi składnikami zaczynu cementowego tworząc kalcyt, wateryt czy aragonit. Krystalizujący w porach węglan wapnia zmniejsza porowatość całkowitą w obszarze skarbonatyzowanym, jednocześnie obniża $\mathrm{pH}$ roztworu w porach betonu powodując obniżenie $\mathrm{pH}$ i zdolności pasywacyjnych betonu wobec stali zbrojeniowej. Także powstający węglan wapnia reagując $\mathrm{z}$ dwu-tlenkiem węgla i wodą tworzy kwaśny węglan wapniowy podlegający procesowi ługowania.

Korozja siarczanowa jest najgroźniejszym typem korozji betonu, a bezpośrednim jej źródłem mogą być spaliny pojazdów silnikowych czy dymy z zakładów przemysłowych lub ciepłowni. Przebieg korozji siarczanowej zależy od stężenia siarczanów oraz od zawartości glinianów w beto-nie. Podczas tego rodzaju korozji powstają, nierozpuszczalne krystaliczne produkty reakcji (ettringit, gips, thaumazyt), które przyłączając wodę zwiększają znacznie swoją objętość i powodują niszczenie mikrostruktury betonu. W elementach żelbetowych następuje niszczenie otuliny zbrojenia (rysy, spękania, złuszczenia) oraz utrata jej zdolności ochronnych [5]. 


\section{Obiekt analiz oraz ich metodyka i wyniki końcowe}

Naprawa obiektów budowlanych jest to proces złożony, mający na celu całkowite lub częściowe przywrócenie obiektowi stanu wyjściowego lub wymaganego projektem stanu użytkowania. Opracowanie podstaw naukowych i wynikających stąd zaleceń technicznych wymaga kompleksowego, systemowego podejścia. Europejski Komitet Normalizacyjny opracował serię dziewięciu norm „Wyroby i systemy do ochrony i napraw konstrukcji z betonu. Definicje, wymagania, sterowanie jakością i ocena zgodności" [1]. Założeniem tej serii norm jest całościowe ujęcie tematyki napraw i ochrony konstrukcji betonowych. Sformułowane w normie metody i zasady mają w większości charakter jakościowy. W normie PN-EN 1504-9 [1] odnośnie zastosowania Zasady 6 - Odporność na czynniki chemiczne zapisano (punkt A.6.2.1.7), iż obejmuje ona wyroby i systemy, które mogą chronić beton przed działaniem agresywnych czynników chemicznych ze środowisk wy-mienionych w normie PN-EN 206-1 [2], a obowiązujące wymagania techniczne [3] ograniczają zwartość procentową chlorków w betonie w zależności od rodzaju konstrukcji.

Przedmiotem badań jest żelbetowy most drogowy, z lat 50-tych ubiegłego wieku, o ustroju trzyprzęsłowym ciągłym o rozpiętościach teoretycznych przęseł $\mathrm{LT}=12,50+16,00+12,50=41,00 \mathrm{~m}$. Szerokość użytkowa wynosi BU $=0,95$ $+7,00+1,25 \mathrm{~m}$; szerokość całkowita obiektu BC=9,50 m (rys. 1).

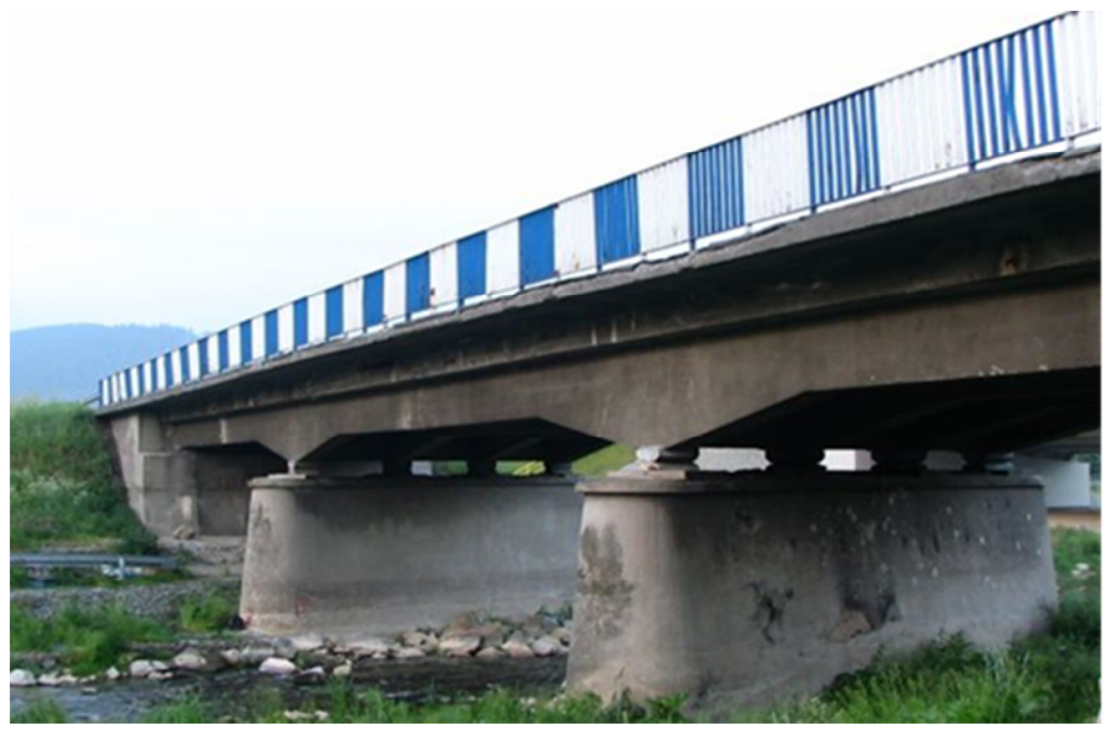

Rys. 1. Widok ogólny analizowanego mostu drogowego

Fig. 1. A view of the analysed bridge

Ustrój nośny stanowi monolityczny żelbetowy ruszt składający się z 4 belek o zmiennej wysokości połączonych ze sobą poprzecznicami i zwieńczonych pły- 
tą grubości $11 \mathrm{~cm}$. Obiekt ten został wzmocniony w $1992 \mathrm{r}$. zespoloną płytą monolityczną gr. $10 \mathrm{~cm}$ z dodatkowymi wspornikami. Na-wierzchnię jezdni stanowi beton asfaltowy o średniej grubości $15 \mathrm{~cm}$. Chodniki znajdują się na wspornikach płytowych o wysięgu poza skrajny dźwigar wynoszącym $1.10 \mathrm{~m}$ (od dolnej wody) oraz $1.40 \mathrm{~m}$ (od górnej wody). Są one monolitycznie połączone z płytą zespoloną i podniesione w stosunku do niej średnio o $0.35 \mathrm{~m}$. Nawierzchnię chodnika stanowi asfalt lany o gr. $3 \mathrm{~cm}$. Podpory mostu to betonowe, zbrojone przyczółki masywne ze skrzydłami wiszącymi żelbetowymi oraz ścienne, trapezowe, pełne filary masywne. Podpory obiektu posadowiono na ławach fundamentowych bezpośrednio na skale. Belki ustroju nośnego mają liczne zacieki a także noszą ślady korozji zbrojenia, oraz znaczne ubytki w betonie w części przęsłowej odsłaniające korodujące pręty zbrojenia głównego. Od spodu dźwigarów występują też liczne kawerny wynikające prawdopodobnie z niskiej jakości robót $\mathrm{w}$ trakcie wykonywania obiektu (niedostateczne zagęszczanie mieszanki betonowej w czasie betonowania ustroju nośnego - szczególnie belek żelbetowych). Ponadto zauważono duże pękniecie (rysę o znacznej rozwartości) dźwigara głównego przedskrajnego. Zarówno spód płyty pomostu, jak i wsporniki podchodnikowe posiadają białe rozległe wykwity spowodowane przeciekami wody z nawierzchni. Zniszczeniu uległy także gzymsy ustroju nośnego mostu. Występują tu liczne ubytki betonu, a w ok. 40 \% nastąpił całkowity ubytek otuliny, zaś pozostałość - odkryte zbrojenie, jest skorodowane. Na skutek tej korozji powierzchnie spodu wsporników pokryte są lokalnie rdzawymi plamami o znacznym zasięgu. Stan techniczny podpór jest na tyle zadowalający, że mogą być one wykorzystane przy remoncie mostu. Po ścianach jednego z przyczółków sączy się woda, co może świadczyć o nieszczelnościach w urządzeniu dylatacyjnym oraz nasączeniu wodą gruntu zasypowego przyczółka w wyniku nieszczelnej nawierzchni jezdni na dojazdach do mostu. Na skrzydłach widoczne są rozległe białe wykwity. Na ławach podłożyskowych zaobserwowano znaczne zacieki i zanieczyszczenia, oraz łuszczący się beton. W warunkach laboratoryjnych oznaczono ilości związków chemicznych. Zawartość wodo-rozpuszczalnych chlorków w betonie określono korzystając z zestawu odczynników Aquamerck 11106 firmy Merck. Z rozdrobnionych próbek betonu przygotowano przefiltrowane roztwory wyj-ściowe z użyciem wody destylowanej (por.[4]). Wyniki badań zawartości chlorków (wartości mak-symalne). w odniesieniu do zawartości cementu w betonie oraz granicznych wartości dopuszczalnych według różnych zaleceń normowych podano w tablicy 1. Oznaczona zawartość chlorków w stosunku do masy cementu w próbkach pobranych z elementów betonowych zależy od głębokości pobrania próby i tak na przykład: dla płyty pomostu na głębokości 40 do $60 \mathrm{~mm}$ wynosi od 0,080 do $0,140 \mathrm{M} \%$; na głębokości od 20 do $40 \mathrm{~mm}$ wynosi od 0,150 do $0,220 \mathrm{M} \%$, a na głębokości 10 do $20 \mathrm{~mm}$ wynosi 0,180 do $0,270 \mathrm{M} \%$. 
Korozja zbrojenia może się rozpocząć wtedy, gdy stężenie jonów chloru przy powierzchni stali osiągnie wartość krytyczną. Według zaleceń amerykańskich (ACI) krytyczna zawartość chlorków określana jest w zawartości procentowej jonów chloru rozpuszczonych $\mathrm{w}$ wodzie w stosunku do masy cementu i nie może przekraczać $0,15 \%$ dla betonu sprężonego i $0,20 \%$ dla żelbetu [5]. W normie europejskiej [2], zgodnie z zaleceniami RILEM przyjęto całkowitą zawartość chlorków nie przekraczającą $0,40 \%$ masy cementu [5]. Dla oceny właściwości ochronnych betonowej otuliny zbrojenia, na podstawie pomiaru zawartości chlorków, można przyjąć dla betonu zbrojonego 0,4 M\% zgodnie z zaleceniami RMTiGM [3] oraz 0,40 M\% zgodnie z PN-EN 206-1 [2] zawartości chlorków w stosunku do masy cementu, powyżej której, szczególnie w betonie skarbonatyzowanym, istnieją warunki do chlorkowej korozji stali zbrojeniowej. Wartości dopuszczalnych zawartości chlorków w betonie zgodnie z [2, 6] uzależnione są od klasy ekspozycji (dla obiektów mostowych XD3). Zalecane wartości graniczne według normatywów są tylko pozornie takie same, bowiem uwzględniając zasady obliczeń dotyczące zaokrąglania oraz uwzględniając niepewność pomiaru zdefiniowanie ilości cyfr po przecinku wpływa na ocenę zgodności. W przypadku skarbonatyzowanego betonu zbrojonego każda zawartość chlorków, zwłaszcza w strefach cyklicznego nawilżania betonu wodami powierzchniowymi oraz w przypadku pogorszonej szczelności betonu, sprzyja korozji stali zbrojeniowej.

\section{Weryfikacja probabilistyczna}

Praktyka budowlana wskazuje, że procedury oceny zgodności nie zawsze spełniają podstawowe wymagania dotyczące ustalania identyczności i jednoznaczności [7]. Wadami są: nieuwzględnianie niepewności wyniku badania, czy odpowiednie uwzględnianie ryzyka producenta czy ryzyka konsumenta. Kolejne problemy pojawiają się gdy dominującym czynnikiem staje się udział niepewności pomiaru. Zagadnieniem istotnej wagi jest zatem użyteczność wyników pomiarów potrzebna do klasyfikacji materiałów na tle niepewności ich pomiaru problem podobny do oceny zgodności czy analizy dotyczącej wykorzystania informacji o niepewności w ocenie zgodności [6]. Dobrze zdefiniowane reguły decyzyjne są nieodzowne w celu weryfikacji jakości materiałów i jednoznacznej oceny zgodności.

Minimalne wartości dopuszczalne zalecane według obowiązujących różnych norm i zaleceń znacznie się różnią (por. Tabela 1). Mogą one określać wartości graniczne z jedną lub dwoma znaczącymi cyframi po przecinku (np. w PNEN 206-1 [2] zalecana wartość to 0,40 M\%, a według RMTiGM [3] to 0,4 M\%) i nie przewidują możliwości porównania ze specyfikacją. Decyzję o ilości cyfr znaczących podejmuje się na początkowym etapie analiz i badań i wpływa ona na ocenę zgodności. Półprobabilistyczna procedura oceny zgodności zalecana w PN EN 206-1 [2] nie uwzględnia współczynników niepewności wynikających 
Tabela 1. Zawartość chlorków w betonie dla wyników badań, na postawie [4]

Table 1. The chloride content of the concrete for test results, based on [4]

\begin{tabular}{|c|c|c|c|c|c|c|}
\hline $\begin{array}{r}\text { Miejsce po- } \\
\text { brania próbki }\end{array}$ & $\begin{array}{c}\text { Głębokość } \\
\text { pobrania } \\
\text { próbki }\end{array}$ & $\begin{array}{c}\text { Chlorki (wartości } \\
\text { maksymalne) } \\
\text { w stosunku do }\end{array}$ & \multicolumn{4}{|c|}{$\begin{array}{l}\text { Zalecane wartości dopuszczalne } \\
\text { według zaleceń normowych }\end{array}$} \\
\hline \multirow{4}{*}{ Plyta } & $00-10$ & 0,270 & \multirow{16}{*}{ 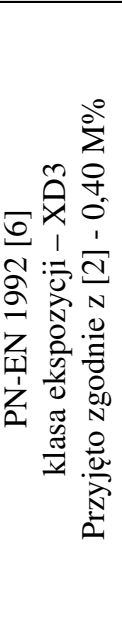 } & \multirow{16}{*}{ 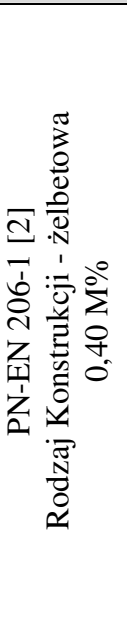 } & \multirow{16}{*}{ 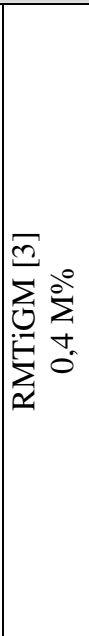 } & \multirow{16}{*}{ 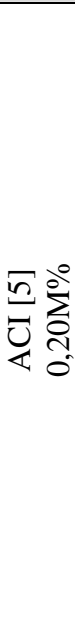 } \\
\hline & $10-20$ & 0,180 & & & & \\
\hline & $20-40$ & 0,220 & & & & \\
\hline & $40-60$ & 0,140 & & & & \\
\hline \multirow{4}{*}{ Belka skrajna } & $00-10$ & 0,280 & & & & \\
\hline & $10-20$ & 0,230 & & & & \\
\hline & $20-40$ & 0,190 & & & & \\
\hline & $40-60$ & 0,090 & & & & \\
\hline \multirow{4}{*}{ Spód gzymsu } & $00-10$ & 0,080 & & & & \\
\hline & $10-20$ & 0,080 & & & & \\
\hline & $20-40$ & 0,090 & & & & \\
\hline & $40-60$ & 0,090 & & & & \\
\hline \multirow{4}{*}{ Spód płyty } & $00-10$ & 0,250 & & & & \\
\hline & $10-20$ & 0,400 & & & & \\
\hline & $20-40$ & 0,190 & & & & \\
\hline & $40-60$ & 0,160 & & & & \\
\hline
\end{tabular}

z pobierania próbek, badania i testowania. W artykule określono prawdopodobieństwo oraz ryzyko przekroczenia wartości progowej dla badanych elementów zgodnie z rozkładem Gamma. Funkcja gęstości prawdopodobieństwa zgodna $\mathrm{z}$ rozkładem Gamma została przyjęta z dwóch powodów:

- jest niemożliwe, aby ujemne wartości przyczyniły się do zwiększenia zawartości chlorków,

- o wartościach ekstremalnych decydują zazwyczaj wartości mniejsze niż średnie [6].

Ryzyko przekroczenia wartości progowej określono korzystając ze zdefiniowanych funkcji Gamma w odniesieniu do zebranych danych. Związek pomiędzy funkcją prawdopodobieństwa a wartością progową określono wzorem:

$$
P_{c}=\Phi\left(T-x_{C l}\right)
$$

gdzie: $P_{c}$ - prawdopodobieństwo zgodności, $T$ - granica tolerancji, $x_{C l}$ - wynik badania.

Określając ryzyko przekroczenia wartości progowej można wykorzystać następującą formulę:

$$
R_{u}=g\left(x_{C l}: a, b\right) \cdot \int_{T}^{\infty}\left[\Phi\left(x_{C l}\right)\right] d x_{C l}
$$

gdzie: $a, b$ - parametry dla zdefiniowanego rozkładu Gamma. 
Tabela 2. Prawdopodobieństwo ryzyka dla zawartość chlorków w betonie i wyników badań, na postawie [4]

Table 2. Probability of risk for the chloride content of the concrete for test results, based on [4]

\begin{tabular}{|c|c|c|}
\hline $\begin{array}{c}\text { Miejsce pobra- } \\
\text { nia próbki }\end{array}$ & $\begin{array}{c}\text { Prawdopodobieństwo ryzyka prze- } \\
\text { kroczenia normowej wartości pro- } \\
\text { gowej }\end{array}$ & $\begin{array}{c}\text { Wartość progowa zdefi- } \\
\text { niowana jako kwantyl 0,95 }\end{array}$ \\
\hline Płyta & $1-0,99=0,01$ & 0,20 \\
\hline Belka skrajna & $1-0,99=0,01$ & 0,24 \\
\hline Spód gzymsu & $1-0,98=0,02$ & 0,22 \\
\hline Spód płyty & $1-0,99=0,01$ & 0,24 \\
\hline
\end{tabular}

Dla określenia prawdopodobieństwa związanego z ryzykiem przekroczenia normowej wartości progowej $0,40 \% \mathrm{M}$ oraz wartości granicznej zdefiniowanej jako kwantyl 95\% dla zawartości chlorków w betonie przyjęto rozkład Gamma. Jeśli w normie PN-EN 1990 [8] oraz normach PN-EN 1991 1999 nie podano inaczej, to kiedy dolna (górna) właściwość materiału jest niekorzystna, jej wartość charakterystyczną przyjmuje się na poziomie $0,05(0,95)$.

Rozkład Gamma przyjęto na podstawie badań i analiz Hinrichs'a (por. [7]). Na rysunku 2 przedstawiono przykładowe dopasowanie teoretycznego rozkładu Gamma dla zebranych wszystkich danych pomiarowych.

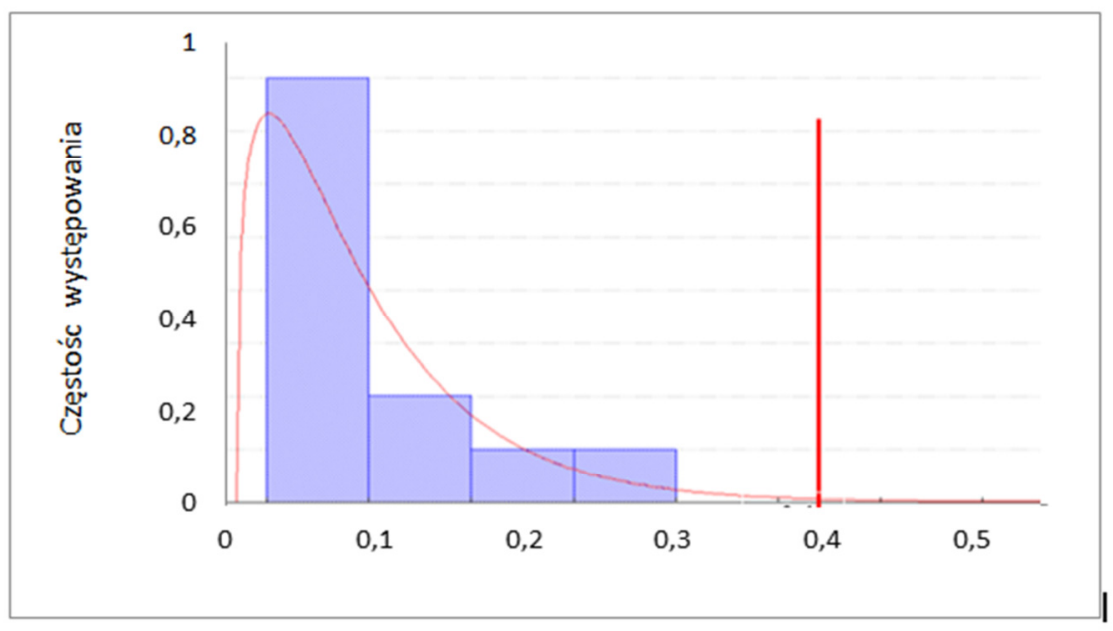

Rys. 2. Dopasowany rozkład Gamma dla zebranych wyników badań

Fig. 2 . The probability density function on the data basis

Analizy przeprowadzono dysponując 12 elementowymi zbiorami danych pomiarowych. Otrzymane prawdopodobieństwa ryzyka przekroczenia normowych wartości progowych dla poszczególnych elementów konstrukcyjnych 
przedstawia tabela 2. Zgodnie z zaleceniami normowymi [1-3,6] dla wartości maksymalnych pokazanych w Tablicy 1 stwierdzono przekroczenie zawartości chlorków tylko dla spodu płyty i głębokości pobierania 10-20 mm. Otrzymane wartości progowe zdefiniowane jako kwantyl $95 \%$ są zbliżone do wartości $0,20 \%$ M zalecanej w normie ACI [4] dla konstrukcji żelbetowych. Dla tak zdefiniowanej wartości progowej zawartości chlorków zostały przekroczone dla wszystkich elementów konstrukcyjnych oprócz spodu gzymsu. Prawdopodobieństwo ryzyka związanego z przekroczeniem wartości normowej jest zatem zawsze mniejsze niż wartość oszacowana dla kwantylu rzędu 0,95, a więc wartości 5\% (Tabela 2).

\section{Podsumowanie}

Przytoczone w pracy zalecenia normowe przewidują procedury oceny zgodności, które są łatwe do zastosowania i identyfikowalne, ale nie są one ani w pełni jednoznaczne, ani metodycznie poprawne. Standardowa procedura pomija oczywiste wpływy takie jak: sposób pobierania próbek, ich przygotowanie czy sposób pomiaru. Niejednokrotne mogą one mieć wpływ na wynik końcowy, który determinuje ocenę materiału konstrukcyjnego.

Standardowa procedura, zdaniem autorów, powinna zawierać reguły zaokrąglania wartości dopuszczalnych. Nie bez znaczenia jest również określenie wartości prawdopodobieństwa zgodności z punktu widzenia ryzyka inwestora/zarządcy oraz przyjęcia odpowiedniego sposobu remontu konstrukcji. Proponowana normowa wartość progowa na poziomie $0,40 \% \mathrm{M}$ dla konstrukcji żelbetowych jest wartością dwukrotnie większą od wartości zalecanej w normie amerykańskiej oraz jest wartością większą od wartości obliczonych dla kwantyla $95 \%$. Korzystając ze standardowej procedury stwierdzono przekroczenie wartości progowej tylko dla spodu konstrukcji. Ryzyko zarządcy/inwestora dla przekroczenia wartości progowej oszacowano na podstawie przyjętych funkcji gęstości na ok. 1\%. Przy wykorzystaniu do oceny zawartości chlorków w betonie metody probabilistycznej można stwierdzić zagrożenie korozją stali zbrojeniowej dla praktycznie wszystkich elementów konstrukcyjnych oraz zwiększone ryzyko zarządcy/inwestora, zdefiniowane na poziomie $5 \%$.

\section{Literatura}

[1] PN-EN 1504-9 Wyroby i systemy do ochrony i napraw konstrukcji z betonu. Definicje, wymagania, sterowanie jakością i ocena zgodności.

[2] PN-EN 206-1: 2003 Beton Część 1: Wymagania, właściwości, produkcja i zgodność.

[3] Rozporządzenie Ministra Transportu i Gospodarki Morskiej w sprawie warunków technicznych jakim powinny odpowiadać drogowe obiekty inżynierskie i ich usytuowanie, Dz.U. Nr 63 z dn. 03.08.2000. 
[4] Wilczak M. i inni, Badania betonu most przez rzekę Krzczonówka w miejscowości Pcim w ciągu drogi krajowej nr 7 km 709+310, Katedra Mostów, Politechnika Rzeszowska im. Ignacego Łukaszewicza, Rzeszów, maj-czerwiec 2007.

[5] Owsiak Z., Ocena stanu betonu w elementach wiaduktu drogowego, Przegląd Budowlany 5/2007, s. 24-27.

[6] PN EN 1992 -1-1:2008. Eurocod 2. Projektowanie konstrukcji z betonu.

[7] Hinrichs W., Compliance assessment of concrete: a probabilistic approach for the content of chlorides, 9-th International Probabilistic Workshop, Braunschweig 2011, s. 209-220.

[8] PN-EN 1990: 2004. Podstawy projektowania konstrukcji. PKN, Warszawa, 2004.

\section{THE ASSESSMENT OF THE TECHNICAL CONDITION OF THE BRIDGE BY THE STUDY OF SELECTED FEATURES OF PHYSICO-CHEMICAL STRUCTURAL PROPERTIES RECOMMENDED BY VARIOUS STANDARDS}

\section{S u m m a r y}

There is an important issue that have a decisive impact in the assessment of the technical condition of the entire structure. It is the quality of material, from which the structure is made. As far as the reinforced concrete bridges on roads are concerned the damage of concrete may be provided either by the carbon dioxide from the atmosphere, or the chloride derived mainly from a salt commonly used for deicing, or the sulfur compounds originating from the exhaust of vehicles. As a result of the combination of these aggressive components occurs the neutralization and/or contamination of concrete. The main aspect of this paper are different recommendations specified by standards for the content of chlorides in concrete construction, and an attempt to verify them by probabilistic approach. The aim of this article is to assess the condition of the concrete in the structural elements of the bridge mainly based on the results of laboratory tests. The study includes the concrete cores obtained from the different elements of the object, which in the macroscopic observations did not exhibit damage by the corrosion. This study of the physical and mechanical properties of concrete, which determined its composition and the content of chlorides, sulphates and extent of carbonation has been performed. Using the standard procedure, we received exceeded the value of chloride in to the bottom of the structure. The risk for the investor exceeding the threshold value was estimated on the basis of the adopted density function for approx. $1 \%$. Using to evaluate the chloride content in the concrete probabilistic method, you can identify risk of corrosion of reinforcing steel for virtually all components and an increased risk of the investor, as defined at the level of $5 \%$.

Keywords: road bridges, concrete, chlorides

DOI: $10.7862 / \mathrm{rb} .2016 .225$

Przestano do redakcji: 24.05.2016 $r$.

Przyjęto do druku: $30.11 .2016 r$. 